\title{
Technè
}

La science au service de l'histoire de l'art et de la préservation des biens culturels

$43 \mid 2016$

Une Europe de la recherche en sciences du patrimoine

\section{Trans-National Access in the field of heritage science at the Laboratory of Ion Beam Applications, MTA Atomki}

Accès transnational dans le domaine des sciences du patrimoine au laboratoire d'applications des faisceaux d'ions du MTA-Atomki

Zita Szikszai, Anikó Angyal, László Csedreki, Enikő Furu, Róbert Huszánk, Zsófia Kertész, Zoltán Szoboszlai, Zsófia Török and Imre Uzonyi

\section{(2) OpenEdition}

\section{Journals}

Electronic version

URL: http://journals.openedition.org/techne/663

DOI: $10.4000 /$ techne.663

ISSN: 2534-5168

Publisher

C2RMF

Printed version

Date of publication: 1 August 2016

Number of pages: 59-62

ISBN: 978-2-7118-6338-9

ISSN: 1254-7867

\section{Electronic reference}

Zita Szikszai, Anikó Angyal, László Csedreki, Enikő Furu, Róbert Huszánk, Zsófia Kertész, Zoltán Szoboszlai, Zsófia Török and Imre Uzonyi, « Trans-National Access in the field of heritage science at the Laboratory of Ion Beam Applications, MTA Atomki », Technè [Online], 43 | 2016, Online since 19 December 2019, connection on 28 July 2020. URL : http://journals.openedition.org/techne/663 ; DOI : https://doi.org/10.4000/techne.663

\section{(c) (†) $\odot$}

La revue Technè. La science au service de l'histoire de l'art et de la préservation des biens culturels est mise à disposition selon les termes de la Licence Creative Commons Attribution - Pas d'Utilisation Commerciale - Pas de Modification 4.0 International. 
Zita Szikszai

Anikó Angyal

László Csedreki

Enikô Furu

Róbert Huszánk

Zsófia Kertész

Zoltán Szoboszlai

Zsófia Török

Imre Uzonyi

Trans-National Access in the field of heritage science at the Laboratory of Ion Beam Applications, MTA Atomki

\author{
Bogdan Constantinescu \\ Angela Vasilescu \\ Catalina Chiojdeanu \\ Daniela Stan
}

Accès transnational dans le domaine des sciences du patrimoine au laboratoire d'applications des faisceaux d'ions du MTA-Atomki
Abstract. The Laboratory of Ion Beam Applications at MTA Atomki served as a Trans-National Access (TNA) host within the CHARISMA EU FP7 project. Although cultural heritage research is only one of the several applications in the laboratory, its importance is growing thanks to the success of CHARISMA. The variety of samples and analytical questions in this field provides constant motivation for development of the instrumentation and adaptation of new techniques. We have special expertise in investigations with high lateral resolution and the PIXE analysis of lighter elements but we can also host projects when the in-vacuum measurements are not feasible, at our external microbeam set-up. We continue the TNA activity within the IPERION CH project.

Keywords. Ion beam analysis, nuclear microprobe, PIXE analysis, PIGE analysis, RBS analysis, archaeometry.
Résumé. Le laboratoire d'applications des faisceaux d'ions au MTA-Atomki a servi de structure-hôte pour l'accès transnational dans le cadre du programme européen CHARISMA. Alors que l'étude des biens culturels n'est que l'une des applications dont s'occupe le laboratoire, elle acquiert une importance grandissante grâce au succès de CHARISMA. La diversité des échantillons et des questions d'analyse dans ce domaine constitue un moteur permanent de développement de l'instrumentation et de l'adaptation des nouvelles techniques. Nous possédons une expertise particulière dans l'imagerie à haute résolution latérale et la méthode PIXE d'analyse des éléments légers, mais nous pouvons accueillir dans notre équipement externe dédié aux micro-faisceaux les projets excluant les mesures sous vide. Nous poursuivons notre activité d'accès transnational dans le cadre du programme IPERION CH.

Mots-clés. Analyse par faisceaux d'ions, microsonde nucléaire, méthode PIXE, méthode PIGE, méthode RBS, archéométrie.

\section{Introduction}

The Institute for Nuclear Research, Hungarian Academy of Sciences (MTA Atomki) is one of the leading establishments in atomic and subatomic physics in Hungary. In addition to basic research, the institute is devoted to the application of atomic and nuclear physics in the fields of environmental research, earth sciences, materials and surface science, biomedicine and, with an increasing interest, cultural heritage research.

A good amount of applied research in MTA Atomki is based on accelerators. The 5MV Van de Graaff accelerator has served as a base for the Laboratory of Ion Beam Analysis (IBA Lab) for decades. The IBA Lab is a multi-disciplinary facility: we are active in aerosol research, radiation chemistry, proton beam writing, just to name a few fields. Through determining the concentration and distribution of elements, ion beam analytical techniques can give information on provenance, authenticity, production technology and degradation due to environmental effects of art and archaeological objects; they may also contribute to the elaboration of conservation technologies. Therefore, several ion beam laboratories are dedicated to some extent to cultural heritage research. Although the first applications in the $\mathrm{CH}$ field dates back to 1990 in the IBA Lab, this kind of investigations were carried out in a rather sporadic way until the launch of the CHARISMA project in 2009. Since then archaeometry has grown to be the second largest area of applications, using up to $20-30 \%$ of beam time of the accelerator, serving both international and national users.

The IBA Lab offers complex ion beam analytical investigations at the scanning nuclear microprobe facility for cultural and natural heritage related research. The available beam size down to $1 \mu \mathrm{m}$ in vacuum provides an important tool for the determination of concentration and distribution of elements with high lateral resolution. The microprobe is

Zita Szikszai (szikszai.zita@atomki.mta.hu), Anikó Angyal, László Csedreki, Enikó Furu, Róbert Huszánk, Zsófia Kertész, Zoltán Szoboszlai, Zsófia Török, Imre Uzonyi, Institute for Nuclear Research, Hungarian Academy of Sciences (MTA Atomki), Hongrie.

Bogdan Constantinescu (bconst@nipne.ro), Angela Vasilescu, Catalina Chiojdeanu, Daniela Stan, "Horia Hulubei” National Institute for Nuclear Physics and Engineering, Bucharest-Magurele, Roumanie. 


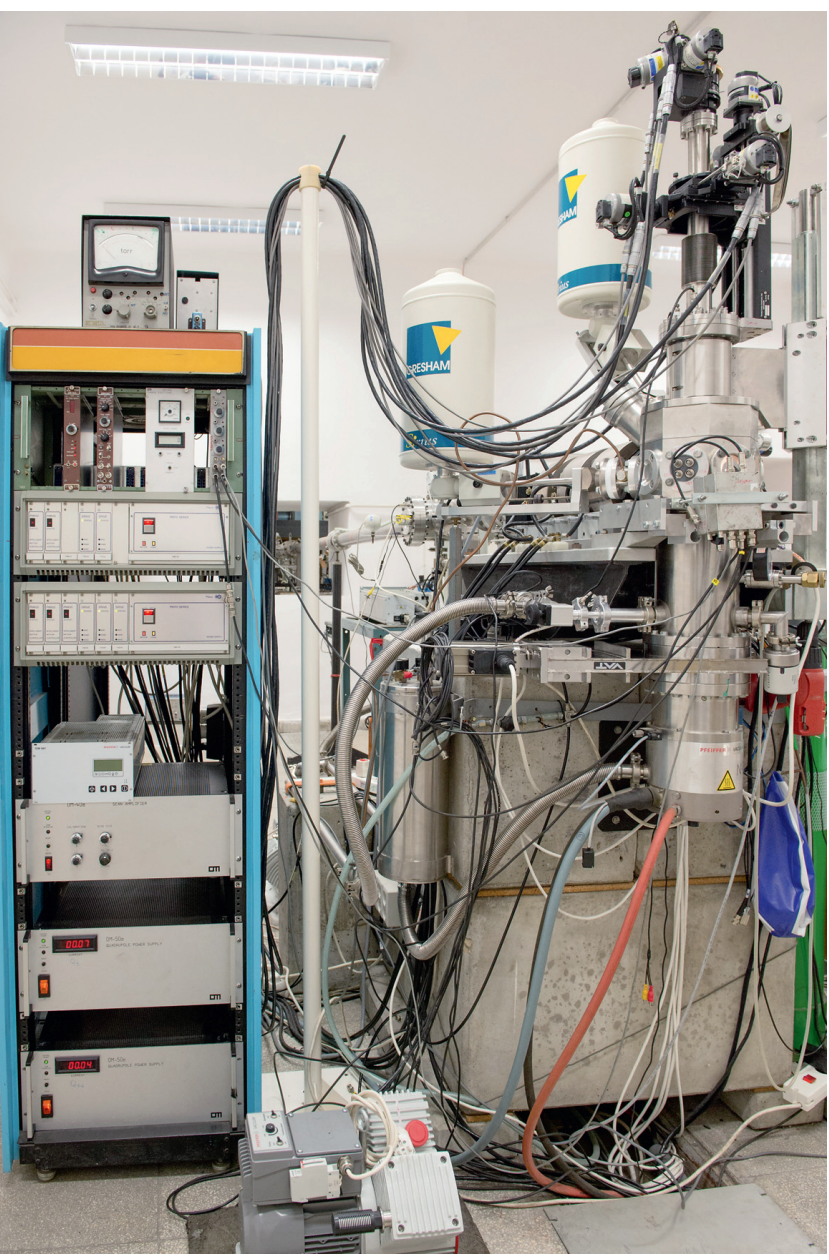

Fig. 1. The nuclear microprobe. (c) Z. Szikszai.

equipped with a 5-axis goniometer (X-Y-Z translations and two rotations), optical microscope, camera and several radiation and particle detectors. The available analytical techniques are particle induced X-ray emission (PIXE), Rutherford backscattering spectrometry (RBS), nuclear reaction analysis (NRA), particle induced $\gamma$-ray emission (PIGE), elastic recoil detection analysis (ERDA), proton elastic scattering analysis (PESA) and scanning transmission ion microscopy (STIM). The detectable elements cover the whole H-U range, although the sensitivities vary. Besides the quantitative elemental composition and distributions, areal density and depth profile can also be determined on microscopic scale. An external micro-beam arrangement is also available for larger artefacts or objects sensitive to vacuum, although some of the IBA techniques are not applicable in this case.

\section{Impact of the CHARISMA project on the IBA Lab}

Based on the above capacities, approximately 1200 hours of beam time at the 5MV Van de Graaff accelerator was dedicated to the CHARISMA project. Twenty-three measurement campaigns were carried out; users arrived from Belgium, Bulgaria, Czech Republic, France, Greece, Finland, Germany, Poland and Romania. The investigated artefacts included metal threads from historical textiles, minerals, glass, Bronze Age and medieval metal objects, ceramics, etc. In all cases major, minor and trace elements were quantified, most of the time by PIXE method, also assessing the distribution of elements. In some cases, $\gamma$-ray and particle detection techniques were also applied to measure light elements below the surface and to identify layer thicknesses, respectively.

The majority of projects came from the fields of archaeology and archaeogeology, making use of the high lateral resolution of the microprobe and the capability to detect light elements with PIXE in vacuum. The variety of materials and objects, as well as the analytical tasks provided continuous stimulation to improve our instrumental capacities. The external micro-beam set-up, for example, was developed based on the needs of end users. We also sharpened our skills in the analytical techniques, gaining new knowledge in specific areas of study. Although the measurements were part of a service with the beam time costs reimbursed by the EU, our contribution always extended beyond that of mere service providers as we grew into the role of genuine partners in archaeological and other cultural heritage related investigations.

Results were presented at various conferences mostly by the partners; several papers have already been published, the dissemination is still ongoing. With all these achievements, we successfully accomplished the CHARISMA TNA programme. Furthermore, with the momentum given by CHARISMA to the cultural heritage related research in our laboratory, we stepped up the cooperation with local partners and also decided to continue research in several topics proposed by CHARISMA TNA users.

\section{IPERION CH and beyond}

As for the present, we are active in the continuation of the CHARISMA project, IPERION CH (Integrated Platform for the European Research Infrastructure ON Culture Heritage). The IBA Lab serves as a host for Trans-National Access. Moreover, combining the irradiating and analytical capacities with competences in materials science, MTA Atomki also contributes to joint research improving methods and practices in cultural heritage diagnostics, especially concerning the safe boundaries of analysis. Complementary spectroscopic techniques such as infra-red (FT-IR), absorption (UV/VIS) and fluorescence (e.g. IBIL) spectroscopy have recently been added to the list of tools to further extend the capabilities of our facility. Although the 5MV Van de Graaff is still fully functional, MTA Atomki has decided to upgrade its accelerator centre with a Tandetron machine with excellent operational parameters. The new accelerator was inaugurated in 2015 and we are currently developing its beamlines. 
Besides ion beam analysis, MTA Atomki is also engaged in cultural heritage research with carbon dating at the Hertelendi Laboratory of Environmental Studies (HEKAL). The accelerator based C-14 technique is available since 2011, giving another boost to the field in our institution. Although AMS C-14 is not part of the IPERION CH TNA programme, we plan its integration into the future national hub of a possible pan-European research infrastructure in heritage science.

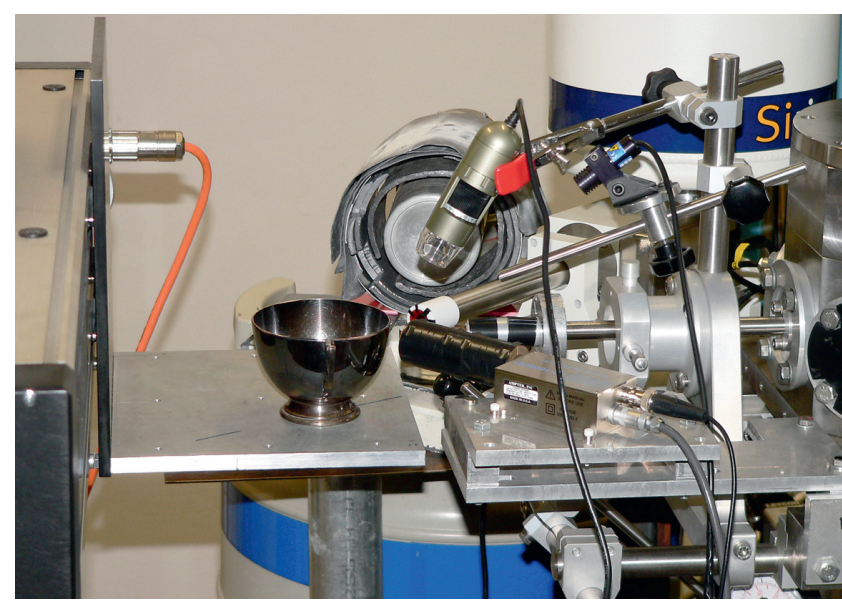

Fig. 2. The external set-up, using an add-on for the vacuum chamber. (c) Z. Szikszai.

\section{Bibliography}

Balta Z. I., Csedreki L., Furu E., Cretu I., Huszánk R., Lupu M., Török Zs., Kertész Zs., Szikszai Z., 2015, "Ion beam analysis of golden threads from Romanian medieval textiles", Nucl. Instr. and Meth. B 348, p. 285-290.

Doncheva S., Tsekova G., Penev I., Nikolova E., Furu E., Szikszai Z., Uzonyi I., 2012, "Elemental composition of metal artifacts from the early medieval centre for artistic metal finds near the village of Novosel, Shumen Region, NE Bulgaria”, Archaeologia Bulgarica 16, p. $67-82$.

Doncheva S., Penev I., Tsekova G., Furu E., Szikszai Z., Uzonyi I., 2013, "Elemental composition of metal artefacts from the 10th c. metal art centre near the Village of Zlatar, Preslav Region, NE Bulgaria”, Archaeologia Bulgarica 17, p. 71-85.
Kostov R. I., Protochristov C., Stoyanov C., Csedreki L., Simon A., Szikszai Z., Uzonyi I., Gaydarska B., Chapman J., 2012, "Micro-PIXE geochemical fingerprinting of nephrite neolithic artifacts from Southwest Bulgaria", Geoarchaeology 27, p. 457-469.

Molnár M., Rinyu L., Veres M., Seiler M., Wacker L., Synal H. A., 2013,

"EnvironMICADAS: A mini ${ }^{14} \mathrm{C}$ AMS with enhanced gas ion source interface in the Hertelendi Laboratory of Environmental Studies (HEKAL), Hungary", Radiocarbon 55, p. 338-344.

Simon A., Matiskainen H., Uzonyi I., Csedreki L., Szikszai Z., Kertész Z., Räisänen J., Kiss Á.Z. 2011, "PIXE analysis of Middle European 18th and 19 th century glass seals", X-Ray Spectrom 40 , p. 224-228.
Török Zs., Huszánk R., Csedreki L., Dani J., Szoboszlai Z., Kertész Zs. 2015,

"Development of a new in-air micro-PIXE set-up with in-vacuum charge measurements in Atomki", Nucl. Instr. and Meth. B 362, p. 167-171.

Uzonyi I., Csontos K., Verebes A., Cserháti Cs., Csedreki L., Kis-Varga M., Kiss Á. Z., 2011, "Characterization of a millefiori glass from Aquincum by SEMEDX and micro-PIXE methods", Nucl. Instr. and Meth. B 269, p. 2389-2392.

Vasilescu A., Constantinescu B., Chiojdeanu C., Stan D., Simon R., Ceccato D., Simon A., Kertész Zs., Szikszai Z., Uzonyi I., Csedreki L., Furu E. 2013, "Elemental characterization of Bronze Age copper objects by micro-beam measurements", Romanian Reports in Physics 65, p. 12221233. 